\title{
SPROUT OF E-ENTERPRISES STIMULATED BY PUBLIC SUPPORT
}

\section{ŁUKASZ KONOPIELKO, ${ }^{1}$ JACEK WYTRĘBOWICZ ${ }^{2}$}

\author{
${ }^{1}$ Łazarski University, Warsaw, POLAND \\ e-mail: konop@gazeta.pl \\ ${ }^{2}$ Institute of Computer Science, Warsaw University of Technology, POLAND \\ e-mail: J.Wytrebowicz@ii.pw.edu.pl
}

\section{RECEIVED \\ ACCEPTED \\ JEL \\ CLASSIFICATION}

KEYWORDS

ABSTRACT
18 January 2018

2 September 2018

D61, $\mathrm{H} 42, \mathrm{O} 32, \mathrm{O} 38$

public grants, innovative economy, e-services valuation, public spending effectiveness

The aim of this paper is to report selected results from an analysis of Internet-based e-services that were created with the support of the EU sponsored Operational Programme for Innovative Economy run by the Polish Agency for Enterprise Development (PARP). From 2008 to 2014, PARP allocated funds for the creation of 2,730 enterprises that develop new e-services. Efficiency of this public support is the focus of this paper; however, there exist no simple means to measure and assess it. Analysis takes advantage of different metrics that can be applied to a numerous set of web pages. The main finding of the paper is that the scheme produced a negative value in terms of its effectiveness, thus raising an issue of rationality of public intervention in Internet-based e-services sector. In comparison with other papers dealing with various subsidy schemes, we did not assume a priori that the subsidy outlays would bring positive effect, allowing for unrestricted assessment of the results obtained in the scheme.

\section{Introduction}

Subsidizing economic activities always is controversial. Numerous arguments have been given as an excuse for channeling public money into private enterprises, including market imperfections and $R+D$ provision as public good alike (Santamaría, Barge-Gil, Modrego, 2010). Moreover, as (Heijs, 2005) argues, although the majority of developed countries have implemented manifold measures of support, yet the evaluation of these instruments 
still proves to be underdeveloped. The evaluation is based generally on the "additionality" principle, which attempts to establish the difference that such support made upon the company performance (Herrera, Bravo, Ibarra, 2010). The difficulties however arise with an appropriate control group and lack of access to the data of an individual beneficiary. Thus, application of classical cost-benefit analysis is allowed, with an attempt to accurately separate benefits brought by public intervention. Moreover, as (Blanes, Busom, 2004) stated, reaching targeted population depends on well-defined selection criteria and procedures for project selection and funding. However, most of the papers dealing with the evaluation focus on the characteristic of the beneficiaries' population (Camisón-Zornoza, Lapiedra-Alcamí, Segarra-Ciprés, Boronat-Navarro, 2004) such as size (Carmichael, 1981) or ability to capture many grants (Lerner, 1999), but what is rare is a search for valuation of final results. Therefore this paper attempts to provide an analysis of the effects of subsidizing e-services projects by studying 2730 specimens involved in the relevant scheme of innovation support in Poland. In doing this, the purpose of the paper is threefold: 1) to identify a methodology of e-services valuation that will be relatively free of above-mentioned evaluation deficits; 2) to analyze the whole sample; 3) to attempt to establish an overall efficiency resulting from the public agency's decisions.

After joining European Union (EU) in 2004, Poland has been the target of an inflow of significant EU structural funds aimed at bridging the development gap, distributed mainly in form of non-returnable grants. Some 14.2 billion EUR was disbursed over 2004-2006 period and almost 68 billion EUR in the years 2007-2013 (Misiag, Misiag, Tomalak, 2013, p. 9). Around $30 \%$ of funds has been directed to enterprises, and over the 2007-2013 period the key leading scheme in this respect was the Operational Programme for Innovative Economy (OPIE). Within its framework, entrepreneurs, business support institutions, research entities and institutions of public administration were granted funding exceeding 10.2 billion EUR for implementation of different kinds of projects that aimed the innovativeness of the economy and enterprises in Poland (more on innovation strategy in Poland in: Prorokowski, 2014). This paper however, will focus on Measure 8.1 of OPIE, which is a unique scheme developed to support the growth of e-services. The purpose of this activity was to stimulate the development of electronic economy, by encouraging the creation of new e-services. Until the end of 2014, 13 calls for projects had been made, attracting all together 15240 applications, out of which 2730 agreements were signed. The amount of awarded funding exceeded $\$ 1$ billion 495 million PLN (equivalent of some 360 million EUR - Table 1 depicts subsidy distribution). Within the scheme, a newly created company could have been granted up to $85 \%$ of eligible costs, subject to a maximum value of 200,000 EUR equivalent. However, both the maximum value of a grant and the share of the subsidy were both decreasing over the 2008-2013 period, down to 130,000 EUR and 70\% respectively over last calls. After its early period in 2008, the programme became so popular in 2009 that allocated funds were not sufficient to cover all the selected projects. This led to a significant change of requirements and resulted in a lower number of eligible applicants from 2010 onwards.

Table 1. Subsidy value distribution_Measure $8.1 \mathrm{OPIE}$

\begin{tabular}{cccccc}
\hline Subsidies number & Subsidies value (PLN) & Mean value & Standard deviation & Max value & Min value \\
\hline 2730 & $1,502,374,719$ & 550,320 & 184,193 & 850,000 & 19,635 \\
\hline
\end{tabular}

Source: own study based on PARP data. 
Measure 8.1 is a unique action in many respects. As a large scale activity focused solely on start-ups offering e-services (compare (Arduini, Zanfei, 2014) for discussion of e-services), it brings a clear perspective for assessing supported companies development as in majority these enterprises were established as new vehicles dedicated solely to the supported activities. Thus, unlike in many development schemes, where publicly backed projects contribute only to a fraction of the company revenue, here an assumption that equates the project value with the company's value can be applied.

Therefore, questions we have posed for the research are: What is the percentage of the created e-services that succeeded against the ones that failed? What is the value of supported e-service? And finally, what is the relation between the value of public funding and the final product of the scheme?

\section{Related Works}

Different techniques and tools for comparison, assessment, valuation and pricing of websites have been widely used for many years. The huge Internet advertising market fuels the development of such tools. Surprisingly, there is very little research related to this subject. Below there are pointed just the most interesting that we have found.

Hu and Zhu (2013) analyze competitive intelligence factors possessed by websites. They argue that analyses of websites factors are an effective way for an enterprise to find its own as well as competitors' strengths and weaknesses. Next, an enterprise can adjust its market competition policies to obtain strategic advantage. Gneiser, Heidemann, Klier, Landherr, Probst (2012) propose an economic model for the valuation of online social networks. The result of their model was in the range of the market capitalization at the instant of XING's valuation.

Other work on value estimation of online social networks was presented by (Mchawrab, 2012). What is interesting is that Mchawrab shows a strong difference between the stock market value of an e-enterprise share and the company fundamentals (based on current book value and value of estimated future cash flows), where the stock market value is surprisingly high.

The mentioned works use website popularity indicators to draw conclusions about e-services or e-businesses in different contexts. The indicators are very useful for the comparison of similar e-services and for the evaluation of an e-service changes over time. Such data are objective and can be gathered automatically for large number of websites.

\section{Approach to Value Analysis of Created E-Enterprises}

The paper attempts to analyze the value of the e-enterprises that appeared thanks to the OPIE. It is worth noting that the rate of success measured in terms of application to grant ratio was $17.21 \%$, while in terms of value awarded to value requested, it amounted to $18.56 \%$ (Moroz, 2014, p. 122). The final number of projects supported, i.e., 2730, is too large for direct interviews or manual assessment of their web pages. Scripts in the Python language were used to automatically query selected valuation services, which are unprotected for automatic queries (e.g. by Captcha code). Our scripts query alexa.com, siteprice.org and worthofweb.com.

1,712 web addresses were found, marking impression about their websites' activity and topicality. We recognized a website as active, if there were visible traces of any changes no older than 5 months. Figure 1 allows one to expect that about $50 \%$ of found webpages evolve, which is a must for e-services' existence. 


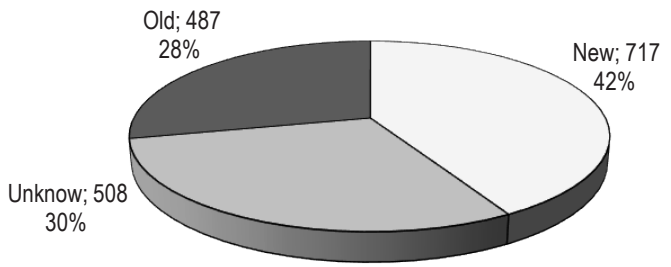

Figure 1. Websites with new content, i.e., no older than 5 months

Source: own study.

The rate of found addresses of all granted projects calculated at $59 \%$ is surprisingly low. It is possible that some projects evolved strongly and some subsidized enterprises changed their names, some grants were allocated for the creation of e-services components, thus the results are invisible as final services. Without in-depth analyses of the grant contracts, it is difficult to determine the number of such projects. Nevertheless, what seems most probable is that most of the e-services that did not appear online just failed (458 contracts terminated). Still, the number of located services is big enough to enable us to draw several conclusions on the sample. Some of the web domains were designed neglecting the aspects of self-promotion, which leads to a decrease in website values. For example, there are 114 e-services where a user has to register to be able to use them, and 14 of them do not provide any information without registration. Moreover, the website worth calculators distinguish neither subdomains of $4^{\text {th }}$ and lower level, nor e-services located as subpages of a given domain. In consequence, those e-services which were located under the umbrella of a corporation website or under the umbrella of a hosting provider enterprise could not be evaluated. There were only 14 such websites in the analyzed set. There were also 23 websites rejected by siteprice.org from assessment due to their content. Siteprice.org adsense policy excludes websites which are suspected to be unsafe or provide restricted content (porn, gambling, poker, casino, violence, etc.)

We gathered data related to the subsidized websites from alexa.com, siteprice.org and worthofweb.com as of 2015. The data allow comparing the value of websites erected as a result of each OPIE call. Below, we shall present selected results from the comparison. Next, we will try to provide conclusions about the efficiency of the subvention programme by juxtaposing the subsidies against the values of the websites.

\section{Assessment of Subsidized Entepprises}

The number of found e-services is substantial. However, Internet visibility does not imply that a service has any users. It is considered that a web page has non-negligible usage, if alexa.com publishes its rank. Our observations of e-services confirm this consideration. Moreover, most valuation services process only the e-services which are ranked by alexa.com. There are only 743 ranked e-services, i.e., $27 \%$ of all subsidized projects, see Figure 2. Only $26 \%$ of all funding yielded e-services of non-negligible usage, see Figure 3 . Analysis of the same distribution per every grant list allows to conclude that the percentage of those not found is greater for older grants while the percentage of those not ranked is greater for younger grants. The observation shows that web sites have to mature to be ranked, and those that are not good enough die with the passing of time. Figure 4 shows the number of grants, found e-services and ranked e-services per grant list. We can infer from it the mentioned observation and that there are no big differences in the proportion of ranked and not ranked e-services per grant list. 


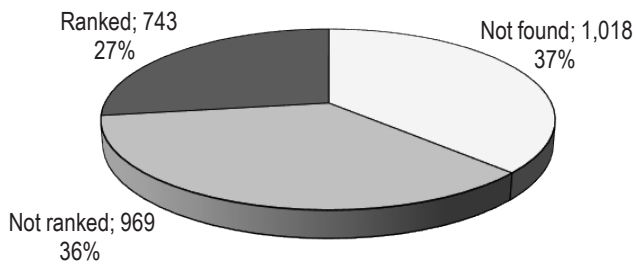

Figure 2. Number of subsidized e-services

Source: own study based on worthofweb.com tool.

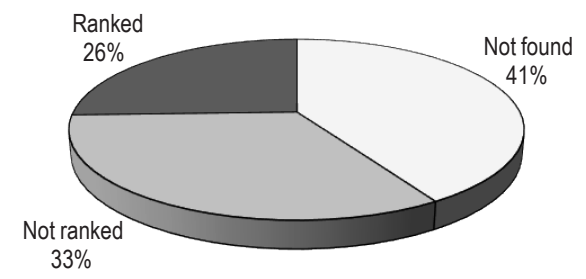

Figure 3. Granted funding for e-services

Source: own study based on worthofweb.com tool.

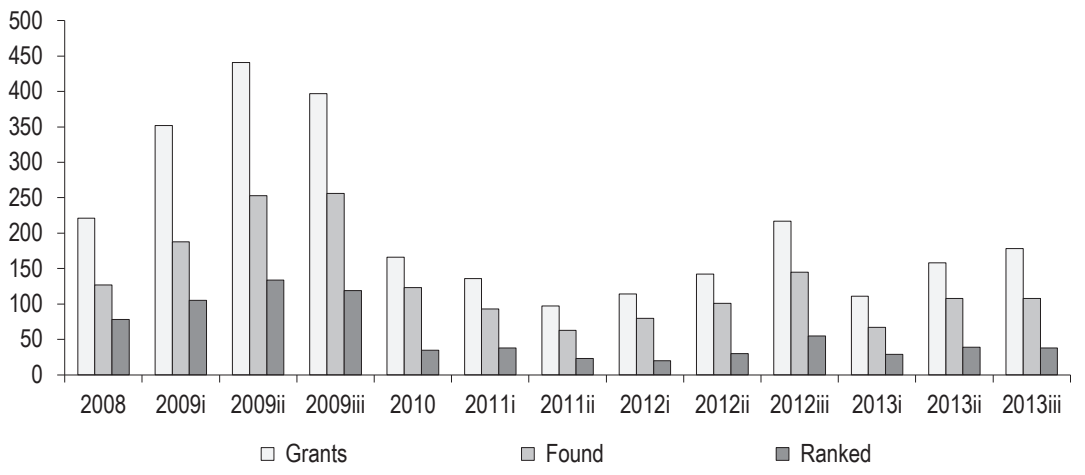

Figure 4. Numbers of grants, found e-services and ranked e-services by alexa.com

Source: own study based on alexa.com tool.

Figure 5 depicts distribution of Alexa ranks per grant list. Due to Alexa algorithm, the big values are very unstable. Median and $1^{\text {st }}$ quartile are more conclusive values. We can observe from them that older e-services are ranked better (lower values) than younger e-services. The explication of it is that a few years have to pass for an e-service to hold significant number of internet users, even though new services arouse interest of web users, and additionally, upon their launch more effort on advertising and search engine optimization is made. 


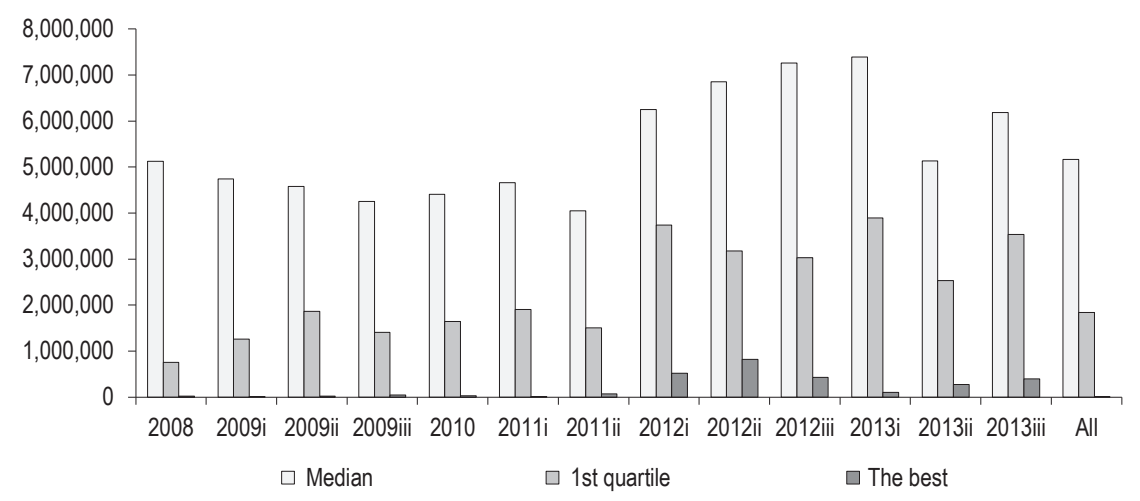

Figure 5. Alexa ranks

Source: own study based on alexa.com tool.

The values gathered from worthofweb.com and siteprice.org are presented in the order from the best to the worst and depicted in Figure 6 . There are very few sites of relatively high value, while all other seem not to differ much. Moreover, SitePrice calculates worth of more websites than WorthofWeb. The reason is that SitePrice processes a website even if there is no Alexa rank for it, while WorthofWeb demands Alexa rank lower (better) than $30,000,000$. Table 2 gives more visible values. The rise of the value for the $95 \%$ of the population is almost linear. Only the best $5 \%$ of the population differ significantly.

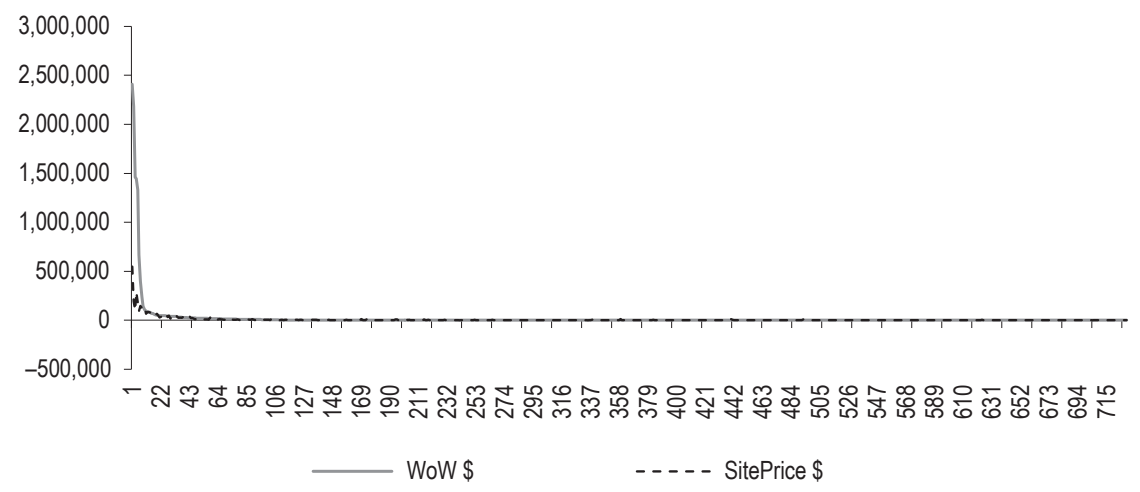

Figure 6 . Website values by worthofweb.com and siteprice.org

Source: own study based on worthofweb.com and siteprice.org tools.

Table 2. Distribution of SitePrice and WorthofWeb values

\begin{tabular}{lrcccc} 
& The best & 1st quartile & Median & 3rd quartile & The worst \\
\hline Site Price \$ & 547,844 & 1,303 & 311 & 94 & 2 \\
WoW \$ & $2,408,800$ & 2,141 & 483 & 105 & 57 \\
\hline
\end{tabular}

Source: own study based on worthofweb.com and siteprice.org tools. 
The values calculated by SitePrice and WorthofWeb differ sharply. There are sites highly valuated by the first calculator and very low by the other and vice versa. Their relative difference (i.e. (WorthofWeb_value SitePrice_value)/WorthofWeb_value) varies from $-7,647 \%$ to $93 \%$, while the median of the relative differences is $-95 \%$. The two calculators use own algorithms, thus it is impossible to state which factors lead to the differences. One noticeable factor is that SitePrice.org adds the estimated value of domain name to its result. Traditional methodologies of enterprise valuation (i.e. current book value, reconstruction value, future cash flows prediction, liquidation value) usually also give very different results, even if applied very meticulously. Hence the discrepancies between SitePrice and WorthofWeb values do not surprise or depreciate them.

\section{Conclusions}

This paper is an attempt to base grant analysis on quantitative data. Our findings can be thus useful in preparation of future grant schemes and subsidy programs. Politicians often argue for public financial support on the base of theoretical and qualitative comparisons. Our findings give opposite arguments, which are based on measured data from a meaningful subsidising program.

From the collected data we can infer that the average value of a supported, visible and measurable e-service is $\$ 3,184$ SitePrice and $\$ 18,101$ Worthofweb, while the mean value of subsidy was 550,320 PLN, i.e., 145,626 USD. Obviously, the estimation of the fundamental value of a company, regardless of its type, cannot be limited to a mere numeric representation. Nevertheless, in the case of the analyzed support scheme an estimated overall return on public investment ranges from 2.34\% (SitePrice, 1,579 cases included) to $12.81 \%$ (WorthofWeb, 708 cases), which brings forward an issue of inefficiency of large-scale publicly organized e-services support schemes. Our results show that it neither leads to the creation of valuable commercial entities in terms of visitor numbers, nor to the development of public-good services, as numerous examples of these represent not upgraded content and their maintenance is limited. Judging by our analysis it is hard to conclude whether it is rather a question of proper selection or perhaps other issues that hamper programme results. But even with an improved selection procedure, any future support scheme would have to cope with the question whether the traditional notion of industrial public support is still applicable to e-services. Perhaps instead of backing the supply side in this case, it is rather the demand-side or just consumers that should be supported in their use of e-services. Alternatively, within the already existing subsidy schemes, financial aid can be provided for actions focused on implementing Internet-oriented dimensions of companies' activities.

\section{References}

Arduini, D., Zanfei, A. (2014). An overview of scholarly research on public e-services? A meta-analysis of the literature. Telecommunications Policy, 38 (5-6), 476-495. Retrieved from: http://doi.org/10.1016/j.telpol.2013.10.007.

Blanes, J.V., Busom, I. (2004). Who participates in R\&D subsidy programs?: The case of Spanish manufacturing firms. Research Policy, 33 (10), 1459-1476. Retrieved from: http://doi.org/10.1016/j.respol.2004.07.006.

Camisón-Zornoza, C., Lapiedra-Alcamí, R., Segarra-Ciprés, M., Boronat-Navarro, M. (2004). A Meta-analysis of Innovation and Organizational Size. Organization Studies, 25 (3), 331-361. Retrieved from: http://doi.org/10.1177/0170840604040039.

Carmichael, J. (1981). The Effects of Mission-Oriented Public R\&D Spending on Private Industry. The Journal of Finance, 36 (3), 617-627. Retrieved from: http://doi.org/10.2307/2327522.

Gneiser, M., Heidemann, J., Klier, M., Landherr, A., Probst, F. (2012). Valuation of online social networks taking into account users' interconnectedness. Information Systems and E-Business Management, 10 (1), 61-84. Retrieved from: http://doi.org/10.1007/ s10257-010-0153-1. 
Heijs, J. (2005). Identification of firms supported by technology policies: the case of Spanish low interest credits. Science and Public Policy, 32 (3), 219-230. Retrieved from: http://doi.org/10.3152/147154305781779515.

Herrera, L., Bravo Ibarra, E.R. (2010). Distribution and effect of R\&D subsidies: A comparative analysis according to firm size. Intangible Capital, 6 (2), 272-299. Retrieved from: http://doi.org/10.3926/ic.2010.v6n2.272-299.

Hu, L., Zhu, M. (2013). Competitive intelligence acquisition from websites. Proceedings - 2013 10th International Conference on Fuzzy Systems and Knowledge Discovery, FSKD 2013, 858-862. Retrieved from: http://doi.org/10.1109/FSKD.2013.6816314.

Lerner, J. (1999). The Government as Venture Capitalist: The Long-Run Impact of the SBIR Program. The Journal of Business, 72 (3), 285-318. Retrieved from: http://doi.org/10.1086/209616.

Mchawrab, S., Reims M.S. (2012). Comment estimer la valeur d'un arbre. Gestion 2000, 29 (3), 45-61.

Misiag, J., Misiąg, W., Tomalak, M. (2013). Ocena efektywności wykorzystania pomocy finansowej Unii Europejskiej jako instrumentu polityki spójności społeczno-gospodarczej oraz poprawy warunków życia. Rzeszów: Wyższa Szkoła Informatyki i Zarządzania.

Moroz, M. (2014). Ocena funkcjonowania działania 8.1 "Wspieranie działalności gospodarczej w dziedzinie gospodarki elektronicznej" Programu Operacyjnego Innowacyjna Gospodarka. Studies \& Proceedings Polish Association for Knowledge Management, 71, 117-128.

Prorokowski, L. (2014). Is investing in innovation an effective strategy in times of crisis? Some evidence from Poland. Innovation: Management, Policy and Practice, 16 (1), 32-52. Retrieved from: http://doi.org/10.5172/impp.2014.16.1.32.

Santamaría, L., Barge-Gil, A., Modrego, A. (2010). Public selection and financing of R\&D cooperative projects: Credit versus subsidy funding. Research Policy, 39 (4), 549-563. Retrieved from: http://doi.org/10.1016/j.respol.2010.01.011.

Cite this article aS: Konopielko, Ł., Wytrębowicz, J. (2018). Sprout of e-enterprises stimulated by public support. European Journal of Service Management, 3 (27/2), 213-220. DOI: 10.18276/ejsm.2018.27/2-26. 